\section{Did smokers shift from small mixed businesses to discount outlets following the introduction of plain packaging in Australia? A national cross- sectional survey}

Opponents of plain packaging (PP) in Australia $^{1-4}$ and elsewhere ${ }^{5-8}$ have claimed that the legislation would create confusion for retailers attempting to locate packs of uniform appearance. This, it was claimed, would result in increases in pack retrieval and overall serving times, ${ }^{9} 10$ impatience with queuing among customers, and a consequent shift in patronage, sales and profits from small mixed businesses to large discount outlets such as supermarkets. ${ }^{10} 11$ Surveys of retailers funded by tobacco industry groups reported perceived negative effects among retailers shortly after implementation of the legislation. ${ }^{12}$ However, studies of retail outlets conducted across Australia over the period of implementation of legislation found no lasting effects on retail serving time ${ }^{13}$ and a study conducted in the Australian state of Victoria 1 year before (2011) and 1 year after (2013) introduction detected no changes among current smokers in usual place of purchase of tobacco products. ${ }^{14}$ We aimed to repeat and extend this analysis using a large national data set.

We used data from continuous national cross-sectional telephone surveys conducted between 9 April 2012 and 30 March 2014 with about 100 respondents per week aged 18-69 years, described fully in Wakefield et $a^{15}$ (this volume).

All respondents were asked 'Do you currently smoke factory-made (FM) cigarettes only, roll-your-own (RYO) cigarettes only, both, or neither of these?' Cigarette smokers (FM and RYO) were asked,
'Where did you buy or get the cigarettes or tobacco you are currently smoking?' For analyses, we coded store types into seven categories: supermarkets, tobacconists, small mixed businesses (including convenience stores, small grocery shops, milk bars, delis and newsagents/newsstands), petrol stations, the internet, duty free or from overseas and other (including informal sellers, bars and pubs, bottle shops and liquor stores, vending machines and 'given as a gift').

Data were weighted to the national smoker/recent quitter population by mobile phone status, gender, age by education and state of residence as described in Wakefield et $\mathrm{al}^{15}$ (this volume). We undertook logistic regression analyses to assess changes in purchase channel between pre-PP (April-September 2012, $n=2193$ ), the transition to PP phase (October and November 2012, $n=765$ ) and the PP phase (December 2012-March 2014,

Table 1 Place of purchase of cigarette smokers' current packs-percentages and results of logistic regression models $(n=7950)$

\begin{tabular}{|c|c|c|c|c|c|c|c|}
\hline \multirow[b]{2}{*}{ Time period } & \multicolumn{3}{|c|}{$\begin{array}{l}\text { Differences between PP phases-unadjusted } \\
\text { modelst }\end{array}$} & \multicolumn{3}{|c|}{$\begin{array}{l}\text { Differences between PP phases—adjusted } \\
\text { modelst‡ }\end{array}$} & \multirow{2}{*}{$\begin{array}{l}\text { Linear trend } \\
\text { post-PP-adjusted models } \\
\text { OR }\end{array}$} \\
\hline & Per cent & $\mathrm{OR}$ & $95 \% \mathrm{Cl}$ & Per cent & OR & $95 \% \mathrm{Cl}$ & \\
\hline \multicolumn{8}{|l|}{ Supermarket } \\
\hline Pre-PP & 57.9 & 1.00 & & 58.1 & 1.00 & & \\
\hline Transition & 55.9 & 0.92 & 0.76 to 1.11 & 55.9 & 0.91 & 0.75 to 1.11 & \\
\hline PP & 57.4 & 0.98 & 0.88 to 1.10 & 57.4 & 0.97 & 0.87 to 1.09 & 1.00 \\
\hline \multicolumn{8}{|l|}{ Tobacconist } \\
\hline Pre-PP & 13.6 & 1.00 & & 13.8 & 1.00 & & \\
\hline Transition & 13.8 & 1.01 & 0.78 to 1.32 & 13.7 & 1.00 & 0.76 to 1.30 & \\
\hline PP & 14.2 & 1.05 & 0.89 to 1.23 & 14.1 & 1.03 & 0.87 to 1.22 & 1.00 \\
\hline \multicolumn{8}{|c|}{ Small mixed business } \\
\hline Pre-PP & 13.7 & 1.00 & & 13.6 & 1.00 & & \\
\hline Transition & 15.7 & 1.17 & 0.90 to 1.54 & 15.6 & 1.17 & 0.90 to 1.54 & \\
\hline PP & 15.4 & 1.15 & 0.98 to 1.35 & 15.5 & 1.16 & 0.99 to 1.37 & 1.01 \\
\hline \multicolumn{8}{|l|}{ Petrol station } \\
\hline Pre-PP & 10.9 & 1.00 & & 10.7 & 1.00 & & \\
\hline Transition & 12.0 & 1.11 & 0.82 to 1.50 & 12.1 & 1.16 & 0.85 to 1.58 & \\
\hline PP & 10.2 & 0.93 & 0.77 to 1.12 & 10.3 & 0.96 & 0.79 to 1.16 & 0.99 \\
\hline \multicolumn{8}{|l|}{ Internet } \\
\hline Pre-PP & $<0.1$ & 1.00 & & - & - & & \\
\hline Transition & 0 & - & - & - & - & - & \\
\hline PP & 0.1 & 8.29 & 0.97 to 71.07 & - & - & - & 0.92 \\
\hline \multicolumn{8}{|c|}{ Duty free or overseas } \\
\hline Pre-PP & 1.9 & 1.00 & & 1.8 & 1.00 & & \\
\hline Transition & 0.7 & $0.36^{*}$ & 0.14 to 0.90 & 0.7 & $0.38^{*}$ & 0.15 to 0.97 & \\
\hline PP & 0.6 & $0.30^{* * *}$ & 0.18 to 0.51 & 0.6 & $0.32^{* * *}$ & 0.19 to 0.53 & 0.94 \\
\hline \multicolumn{8}{|l|}{ Other source } \\
\hline Pre-PP & 2.0 & 1.00 & & 2.0 & 1.00 & & \\
\hline Transition & 2.0 & 1.04 & 0.55 to 1.98 & 2.1 & 1.05 & 0.55 to 2.00 & \\
\hline PP & 2.0 & 1.02 & 0.69 to 1.52 & 2.0 & 1.03 & 0.69 to 1.52 & 0.99 \\
\hline
\end{tabular}


$\mathrm{n}=5721$ ). We also tested whether there were linear changes over the months during the PP phase, as unintended consequences of PP could occur gradually. We controlled for sex, age (18-29, 30-49 and 50-69 years), area-based socioeconomic status ${ }^{16}$ and education.

As shown in table 1, odds of reporting purchase from major channels such as supermarkets, tobacconists, small mixed businesses and petrol stations did not change between the pre-PP and PP phases. The adjusted proportion whose latest pack was purchased duty free or overseas declined from $1.8 \%$ pre-PP to $0.7 \%$ in the transition phase and $0.6 \%$ during $\mathrm{PP}$. Purchase of packs over the internet or from 'other sources' was negligible throughout the survey. No gradual changes in place of purchase were detected during PP (table 1).

Excise/customs duty on tobacco products in Australia increased by $12.5 \%$ on 1 December 2013. The resulting increases in prices may have prompted some consumers to shift from convenience outlets (where tobacco products tend to be sold at or close to recommended retail prices) to outlets such as supermarkets and tobacconists (where tobacco products tend to be more heavily discounted). ${ }^{17}$ When we excluded data from cases collected after this tax increase, the percentage of respondents who reported purchasing from small mixed businesses increased significantly between pre-PP (13.6\%) and PP year 1 (15.8\%; adjusted OR=1.19, 95\% CI 1.01 to $1.41, \mathrm{p}=0.039)$ and increased linearly over the months during PP year 1 (adjusted $\mathrm{OR}=1.03$, 95\% CI 1.01 to $1.06, \mathrm{p}=0.038)$-results not in table.

This survey provides no evidence of a shift to overseas or duty-free purchase. This was to be expected given the reduction in the limit for import of duty-free cigarettes - from 200 to 50 cigarettes per personthat came into force in September 2012. ${ }^{18}$

The results of this large national study confirm those of our earlier study conducted in Victoria which also found no decline in percentages of smokers purchasing from convenience outlets following the introduction of PP. ${ }^{14}$ Findings of our study corroborate sales data from international market research company, Euromonitor, which suggest no major shifts in channel of purchase between 2012 and 2013. ${ }^{19}$

Michelle Scollo, Kerri Coomber, Meghan Zacher, Melanie Wakefield

Centre for Behavioural Research in Cancer, Cancer Council Victoria, Melbourne, Victoria, Australia

Correspondence to Dr Michelle Scollo, Centre for Behavioural Research in Cancer, Cancer Council Victoria, 615 St Kilda Rd, Melbourne, VIC 3004 , Australia; mscollo@cancervic.org.au
Acknowledgements The authors thank Ms Megan Bayly for data checking and review.

Contributors MS and MW designed this study. MZ cleaned data files, undertook analysis and reported results. MS drafted the manuscript with contributions from all authors. KC undertook further analysis. All authors approved the final manuscript.

Funding The National Plain Packaging survey was funded under a contract with the Australian Government Department of Health and Ageing.

Competing interests The authors wish to advise that MS was a technical writer for and MW a member of the Tobacco Working Group of the Australian National Preventive Health Task Force and MW was a member of the Expert Advisory Committee on Plain Packaging that advised the Australian Department of Health on research pertaining to the plain packaging legislation. MW holds competitive grant funding from the Australian National Health and Medical Research Council, US National Institutes of Health, Australian National Preventive Health Agency and BUPA Health Foundation.

Ethics approval The survey was approved by the Cancer Council Victoria Human Ethics Committee (HREC 0018).

Provenance and peer review Not commissioned; externally peer reviewed.
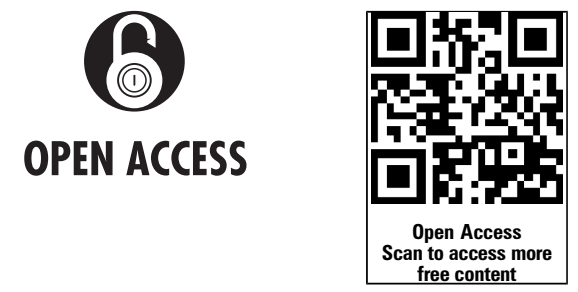

Open Access This is an Open Access article distributed in accordance with the Creative Commons Attribution Non Commercial (CC BY-NC 4.0) license, which permits others to distribute, remix, adapt, build upon this work non-commercially, and license their derivative works on different terms, provided the original work is properly cited and the use is noncommercial. See: http://creativecommons.org/licenses/ by-nc/4.0/

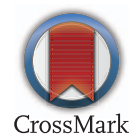

To cite Scollo M, Coomber K, Zacher M, et al. Tob Control 2015;24:ii98-ii100.

Received 15 December 2014

Accepted 12 January 2015

Tob Control 2015:24:ii98-ii100.

doi:10.1136/tobaccocontrol-2014-052199

\section{REFERENCES}

1 British American Tobacco Australia. Submission on the tobacco plain packaging bill 2011. Canberra: Department of Health and Ageing Consultation website, 2011. http://content.webarchive.nla.gov.au/gov/wayback 20130904173432/http://www.yourhealth.gov.au/ internet/yourhealth/publishing.nsf/Content/ 2EE2F6F3EC74F628CA2579540005F68B/\$File/British\% 20American\%20Tobacco\%20Australia\%20-\%20Public \%20Submission.pdf (accessed Oct 2014).

2 Philip Morris Limited. Commoditising tobacco products through plain packaging will harm public health, violate treaties and does not meet the test of evidence-based policy'. Melbourne, 2011. http:// webarchive.nla.gov.au/gov/20130329051831/http:// www.yourhealth.gov.au/internet/yourhealth/ publishing.nsf/Content/Phillip-Morris-Limited PhillipMorris-Limited-2 (accessed Oct 2014).

3 Imperial Tobacco Australia Limited. Submission to the Department of Health and Ageing regarding the tobacco plain packaging bill 2012 (exposure draft) and consultation paper. Sydney, 2011. http://webarchive. nla.gov.au/gov/20130329044623/http://www. yourhealth.gov.au/internet/yourhealth/publishing.nsf/ Content/ppit ncr loe (accessed 10 Jan 2012).

4 Alliance of Australian Retailers. Submission on the exposure draft of tobacco plain packaging bill and House Standing Commitee on Health and Ageing Inquiry. 2011. https://www.australianretailers.com.au/

5 British American Tobacco (BAT). UK Standardised Packaging Consultation: Response of British American Tobacco UK Limited. 2012. http://www. bat.com/group/sites/uk__3mnfen.nsf/ vwPagesWebLive/D08WZC5E/\$FILE/medMD8WZC6J. pdf?openelement (accessed May 2014).

6 Japan Tobacco International ( JTI). Response to the Department of Health's consultation on the standardised packaging of tobacco products. 2012 http://www.jti.com/how-we-do-business/ key-regulatory-submissions/ (accessed May 2014).

7 Oireachtas Joint Committee on Health and Children. Public health (standardised packaging of tobacco) bill presentations and submissions. Dublin: Houses of the Oireachtas, 2014. http://www.oireachtas.ie/ parliament/oireachtasbusiness/committees_list/ health-and-children/submissionsandpresentations/ (accessed May 2014).

8 British American Tobacco (New Zealand) Ltd. Proposal to introduce plain packaging of tobacco products in New Zealand: submission by British American Tobacco (New Zealand) Limited. Wellington: Parliament of New Zealand, 2014. http:/ www.parliament.nz/en-nz/pb/sc/documents/evidence? Custom=00dbhoh_bill12969_1\&Criteria.

PageNumber $=2$ (accessed May 2014)

9 Deloitte. Potential impact on retailers from the introduction of plain tobacco packaging. Sydney: Alliance of Australian Retailers, 2011. https://www. australianretailers.com.au/research.php

10 Tobacco Retailers Alliance. Submission to Chantler independent review or plain packaging. London: Kings College, 2014. http://www.kcl.ac.uk/health/ packaging-docs.aspx

11 Deloitte. Plain packaging and channel shift. Sydney: Alliance of Australian Retailers, 2011. https://www. australianretailers.com.au/downloads/pdf/deloitte/ Potential_impact_of_channel_shift.pdf

12 Australian Association of Convenience Stores. Impact of plain packaging on small retailers - wave 2 . 2013. http://www.aacs.org.au/wp-content/uploads/ 2013/10/Impact-of-Plain-Packaging-on-SmallRetailers-W2-Final-Report.pdf

13 Bayly M, Scollo M, Wakefield M. No lasting effects of plain packaging on cigarette pack retrieval time in small Australian retail outlets. Tob Control 2015;24: e108-9.

14 Scollo M, Zacher M, Durkin S, et al. Early evidence about the predicted unintended consequences of standardised packaging of tobacco products in Australia: a cross-sectional study of the place of purchase, regular brands and use of illicit tobacco. BMJ Open 2014;4:e005873.

15 Wakefield M, Coomber K, Zacher M, et al. Australian adult smokers' responses to plain packaging with larger graphic health warnings 1 year after implementation: results from a national cross-sectional tracking survey. Tob Control 2015;24:ii17-25.

16 Australian Bureau of Statistics. Technical paper: socio-economic indexes for areas (SEIFA) 2011 Canberra, Australian Capital Territory: ABS, 2013. http:/l www.abs.gov.au/websitedbs/censushome.nsf/home/ 
seifa2011 ?opendocument\&navpos=260 (accessed Apr 2014).

17 Scollo M, Bayly M. Section 13.3 The price of tobacco products in Australia in Chapter 13. The pricing and taxation of tobacco products in Australia (December 2014 update). Melbourne, Australia: Cancer Council
Victoria, 2014. http://www.tobaccoinaustralia.org.au/ chapter-13-taxation/13-3-the-price-of-tobaccoproducts-in-australia.

18 Customs By-Law No. 1228133, (2012). http://www. customs.gov.au/webdata/resources/files/

BL1228133web.pdf
19 Freeman B. Chapter 10. The tobacco industry in Australian society, Section 10.3 Retail value and volume, Updated September 2014. Melbourne: Cancer Council Victoria, 2013. http://www. tobaccoinaustralia.org.au/chapter-10-tobacco-industry 